\title{
Estimation of Shelf Life on Pollard and Bran with Arrhenius Model on Storage at Different Temperatures
}

\author{
Rizqa Adisti AZ a ${ }^{*}$, Indah Wijayanti b, Yuli Retnaini c \\ $a, b, c$ Department of Nutrition Science and Feed Technology, IPB University, Bogor, Indonesia \\ email: "rizqaptk233@gmail.com,indah_wiynt@yahoo.com,yuliretnaini@gmail.com
}

\begin{tabular}{l}
\hline A R T I C L E I N F O \\
\hline Article history: \\
Received 23 September 2021 \\
Revised 11 October 2021 \\
Accepted 23 Desember 2021 \\
Available online 31 December \\
2021
\end{tabular}

\section{Keywords:}

Arrhenius,

Peroxide number,

Pollard,

Wheat bran

IEEE style in citing this article:

(R. A AZ, I. Wijayanti and Y. Retnaini, "Estimation of Shelf Life on Pollard and Bran with Arrhenius Model on Storage at Different Temperatures," Jurnal Ternak, vol. 12, no. 2, pp. $61-67,2021$.

\section{A B S T R A C T}

Fluctuating climatic and transportation conditions in Indonesia cause problems in the storage of feed ingredients. Estimating the shelf life of feed ingredients is very important to know in order to help the feed industry in the storage, availability and maintenance of the quality of the feed produced. The purpose of this study was to determine the shelf life of pollard and wheat bran at different storage temperatures based on the value of the peroxide number using the Arrhenius model. In determining shelf life, pollard and wheat bran were stored at 15,35 , and $45^{\circ} \mathrm{C}$ for 49 days. The parameter used in this research is the peroxide number. The results of this study were based on the calculation of the Arrhenius model in pollard based on the number of peroxides at a temperature of 15,35 and $45^{\circ} \mathrm{C}$, the shelf life of which was 27.3 months, 22.2 months and 13.1 months, respectively. The shelf life of wheat bran is 25.1 months, 15.1 months and 14.8 months. The conclusion is that the temperature and storage time are directly proportional to the peroxide number. Meanwhile, temperature and storage time are inversely proportional to shelf life.

Jurnal Ternak (Animal Science Journal) Faculty of Animal science - Lamongan Islamic University) with CC BY NC SA license.

\section{Introduction}

Industrial development in Indonesia demands the availability of cheap feed ingredients, can be available at any time and does not compete with human needs. Pollard and wheat bran are by-products of wheat. Pollard is the outer part of the wheat while wheat bran is the inner part of the wheat. the second product that is commonly used as fodder for poultry and ruminants. Uncertain transportation conditions cause factories to store pollard and wheat bran will cause fluctuations in the presence of pollard and wheat bran. Fluctuations in the presence of pollard and wheat bran cause the feed industry to carry out large-scale storage as stock materials for the production process. The purpose of the storage is to maintain the availability of materials but storage that is too long can cause rancidity and reduce the quality of the ingredients. Decreasing the quality of feed ingredients will affect the quality of the feed products produced, which will reduce the quality of nutrients that must be produced by livestock. This happens because the shelf life of pollard and wheat bran is unknown, so that the feed industry has difficulty managing raw materials. Efforts that can be made to overcome this to determine the age of pollard and wheat bran.

Pollard and wheat bran that are stored too long usually give off rancid odor. Rancidity is one type of food spoilage that can be used as a parameter for rejecting food quality [1]. Rancidity occurs in 
foods that contain fat. Rancidity of fats is caused by oxidation (oxidative rancidity), rancidity by enzymes (enzymatic rancidity), and rancidity due to the hydrolysis process (hydrolytic rancidity) [2]. Oxidative rancidity occurs due to the oxidation process by air oxygen into unsaturated fatty acids in fat [3]. The oxidation process generally occurs at room temperature, the higher the temperature, the faster the oxidation process occurs. The results of fat oxidation in feed ingredients not only cause unpleasant tastes and odors, but can also reduce the nutritional value, due to damage to vitamins (carotene and tocopherols) and essential fatty acids in fat which of course reduces the nutrients that should be obtained by livestock. The main breakdown of fat is the appearance of a rancid odor and taste called the process of rancidity. This is due to the autoxidation of unsaturated fatty acid radicals in the fat. Free fatty acids with $\mathrm{O} 2$ form active peroxides which can form unstable and easily broken hydroperoxides [4]. The peroxide number is a method used to measure the rancidity of a substance. Peroxide number indicates fat oxidation due to heat and oxygen [5]. The free fatty acids present in the product will be oxidized by oxygen and heat to peroxide which is an early indicator of fat oxidation [6].

Rancidity is one indicator of a decrease in the quality of feed ingredients. The more rancid, the worse the quality of the feed. Decreasing the quality of feed ingredients also affects the shelf life of feed ingredients, the lower the quality of feed, the shorter the shelf life of a feed ingredient. The method that can be used to determine the age of feed is the Accelerated Shelf Life Test (ASLT) this method accelerates the decline in product quality by storing the product in extreme conditions (high temperature and humidity) so that the determination of shelf life is shorter. ASLT method has two models, namely the Arrhenius model and the critical moisture content model. The Arrhenius model is suitable for food products that are sensitive to temperature, fat oxidation, maillard reactions and protein denaturation while the critical moisture content model is suitable for air sensitive feed ingredients [7]. The purpose of this study was to determine the shelf life of pollard and wheat bran stored at different temperatures using the Arrhenius model acceleration method based on the value of the peroxide number.

\section{Method}

The ingredients used in this study were pollard and wheat bran which were obtained from a centralized feed store in east Jakarta. The main chemicals used are n-hexane, glacial acetate, sodium thiosulfate, starch indicator obtained by the Citra Sari Kimia shop in central Jakarta. This research referred to [8] tests on the estimation of shelf life on pollard and wheat bran with the Arrhenius method were carried out at three storage temperatures representing cold, temperature room and hot temperature at 15,35 , and $45^{\circ} \mathrm{C}$ for 7 weeks. Sampling was carried out on days 7, 21, 35 and 49 to the peroxide value, after the peroxide number data is known. Afterwards, Arrhenius model test was conducted to determine the shelf life of pollard and wheat bran.

\subsection{Peroxide number}

The determination of the peroxide number begins with the manufacture of extracts of pollard and white brand using cold maceration techniques. Pollard and wheat bran that has been stored in an incubator at 15,35 , and $45^{\circ} \mathrm{C}$ is weighed $250 \mathrm{~g}$ then put into Erlenmeyer and then added n-hexane solvent until the sample was completely immersed. Furthermore, the sample was stirred in order to completely mixed and closed tightly, then macerated at room temperature for 24 hours. The filtration result was then collected (filtrate I). The waste from filtrate I was then added with n-hexane until the sample was completely immersed and macerated again for 24 hours, stirred for 5 minutes and filtered with coarse filter paper (filtrate II). The filtrate I and II were mixed and filtered with filter paper. The filtrate was then evaporated with a rotary evaporator at a temperature of $40^{\circ} \mathrm{C}$ with a pressure of 100 mBar to remove the solvent contained in the extract until all the solvent has evaporated which was indicated by the solvent not dripping again in a minimum period of 5 minutes. The viscous extract obtained was put into a sample bottle [9].

The determination of the peroxide number is used to determine the equivalent concentration of peroxide resulting from the oxidation of fat in the sample (megperoxide $/ \mathrm{kg}$ sample) [10]. Based on the [10], $5 \mathrm{~g}$ of the extract was put into a closed erlenmeyer and $30 \mathrm{~mL}$ of a mixture of glacial acetic acid: chloroform (3: $2 \mathrm{v} / \mathrm{v} \mathrm{v} / \mathrm{v})$ was added. After the sample is completely dissolved, $0.5 \mathrm{~mL}$ of saturated KI 
solution is added and left for 5 minutes while shaking, then $30 \mathrm{~mL}$ of distilled water is added. Iodine liberated by peroxide is titrated with $0.1000 \mathrm{~N}$ standard solution of sodium thiosulfate (Na2S2O3) with starch indicator until the blue color disappears. The peroxide number is expressed by the following calculation formula:

$\mathrm{N}=$ Normality $\mathrm{Na}_{2} \mathrm{~S}_{2} \mathrm{O}_{3} 0,01 \mathrm{~N}$

$$
\text { Peroxide number }=\frac{(\mathrm{mL} \text { titration }-\mathrm{mL} \text { blank }) \times \mathrm{N} \times 1000}{\text { sample weight }}
$$

\subsection{Arrhenius Model}

The results of the observations for each parameter of quality degradation have calculated the rate of quality degradation per week (reduction in quality units per week or k) by plotting in a graph the relationship between the value of ln quality deterioration activity when following reaction order one and the activity value of water content only when following a zero reaction order [11]. This value is the $y$-axis and storage time, namely the $0,1,3,5$ and 7 days as the $x$-axis at each storage temperature (15, 35 , and $45^{\circ} \mathrm{C}$ ). Then look for the value of $\mathrm{k}$ or the value of the constant decline in quality per day obtained from the slope of the regression equation of the two graphs. After the $\mathrm{k}$ value is obtained, the $\ln \mathrm{k}$ value is sought for each storage temperature. Then an Arrhenius plot is made, with the $x$-axis representing the value of $1 / \mathrm{T}(\mathrm{K}-1)$ and the $\mathrm{y}$-axis representing the value of $\ln \mathrm{k}$ at each storage temperature used (15, 35 , and $45^{\circ} \mathrm{C}$ ). The $\mathrm{k}$ value is the gradient of the linear regression obtained from the three storage temperatures. From the linear regression obtained on the Arrhenius curve it can be predicted the shelf life of the product using the formula:

$$
\mathrm{k}=\mathrm{ko} \cdot \mathrm{e}^{-\mathrm{Ea} / \mathrm{RT}}
$$

$\mathrm{k}=$ deterioration constant; $\mathrm{ko}=$ constant (independent of temperature); $\mathrm{Ea}=$ activation energy; $\mathrm{T}=$ absolute temperature $(\mathrm{K}) ; \mathrm{R}=$ constant gas $(1.986 \mathrm{kal} / \mathrm{mol} \mathrm{K})$

ko is a constant for deterioration of the product that is independent of temperature, while $\mathrm{k}$ is a constant for deterioration of one of the temperature conditions used $\left(15,35\right.$, and $\left.45^{\circ} \mathrm{C}\right)$ and $\mathrm{Ea} / \mathrm{R}$ is the gradient obtained from the Arrhenius plot. By calculating using this formula, the value of ko will be obtained. The shelf life according to reaction order one is obtained by the formula [12]:

$$
\mathrm{t}=\frac{\operatorname{InAo-InAt}}{\mathrm{Ko}}
$$

$\mathrm{t}=$ prediction of shelf life (day); $\mathrm{Ao}=$ initial quality value; $\mathrm{At}=$ product quality value remaining after time $\mathrm{t} ; \mathrm{ko}=$ constant. from the formula above, we can predict the shelf life in days or months

\section{Results and Discussion}

The peroxide number is an index of the amount of fat or oil that has undergone oxidation. The peroxide number is very important for the identification of the oxidation state. The high peroxide value describes the high oxidation that occurs in a feed ingredient. The following is the peroxide value in pollard and wheat bran for 49 days of storage.

Table 1. Changes in the value of peroxide in pollard and wheat bran during storage

\begin{tabular}{ccccccc}
\hline \multirow{2}{*}{ Feed } & \multirow{2}{*}{ Temperature $\left({ }^{\circ} \mathbf{C}\right)$} & \multicolumn{5}{c}{ Storage Time (Day) } \\
\cline { 3 - 7 } & & $\mathbf{1}$ & $\mathbf{7}$ & $\mathbf{2 1}$ & $\mathbf{3 5}$ & $\mathbf{4 9}$ \\
\hline \multirow{3}{*}{ Pollard } & 15 & $0.20 \pm 0.02$ & $0.29 \pm 0.01$ & $0.62 \pm 0.03$ & $0.91 \pm 0.03$ & 1.07 \\
& 35 & $0.20 \pm 0.01$ & $0.32 \pm 0.02$ & $0.72 \pm 0.04$ & $1.08 \pm 0.04$ & 1.20 \\
\multirow{3}{*}{ Wheat } & 45 & $0.24 \pm 0.03$ & $0.63 \pm 0.01$ & $0.96 \pm 0.02$ & $1.22 \pm 0.03$ & 1.38 \\
Bran & 15 & $0.16 \pm 0.03$ & $0.16 \pm 0.02$ & $0.23 \pm 0.04$ & $0.39 \pm 0.02$ & 0.47 \\
& 35 & $0.34 \pm 0.02$ & $0.63 \pm 0.03$ & $0.81 \pm 0.02$ & $1.03 \pm 0.02$ & 1.28 \\
& 45 & $0.34 \pm 0.02$ & $0.68 \pm 0.02$ & $0.89 \pm 0.02$ & $0.91 \pm 0.03$ & 1.43 \\
\hline
\end{tabular}


Based on Table 1, it is known that the highest peroxide number value occurs in wheat bran with a storage temperature of $45^{\circ} \mathrm{C}$ on the 49 th day of storage, $1.43 \mathrm{meg} 02 / 100 \mathrm{~g}$ of oil. While the lowest peroxide number occurs in wheat bran which is stored at $15^{\circ} \mathrm{C}$ on the first day of storage, when compared to the temperature level with the peroxide number it is known that the higher the storage temperature will produce a large peroxide number. This happens with pollard and wheat bran, this proves that the peroxide number is affected by the storage temperature. In the storage time of the two types of feed ingredients the peroxide number tends to increase along with the length of the shelf life, this proves that the shelf life affects the value of the peroxide number that occurs in pollard and wheat bran. Oxidation is supported by oxygen and light. In this study, pollard and wheat bran were stored at $45^{\circ} \mathrm{C}$, the temperature setting uses hot light so that this supports higher oxidation than pollard and wheat bran stored at room temperature. Pollard and wheat bran which are continuously exposed for 24 hours for 49 days help break down fatty acids so that there are lots of free fatty acids that cause the formation of acrolein and glycerol. This acrolein compound causes the odor and feed ingredients to turn black. The high peroxide number on the 49th day of storage was also assisted by oxygen because in this study pollard and wheat bran were stored in an open container which facilitated the interaction of oxygen with feed ingredients. Pollard and wheat bran damage during storage will affect the quality and quality of the feed ingredients that will be used to make feed. Although the value of the peroxide number produced in this study is still far from being toxic, $100 \mathrm{meg} 02 / 100 \mathrm{~g}$ of oil. Nonetheless, it is very important to know the shelf life of pollard and wheat bran, so this research is continued in a trial of the Arrhenius model of acceleration.

The Arrhenius model is a simple simulation model to estimate the rate of deterioration in product quality [13]. The Arrhenius model is an approach that quantifies the effect of temperature on deterioration values and determines shelf life. The data were analyzed using simple linear regression analysis. The Arrhenius model is an approach that quantifies the effect of temperature on the value of deterioration and determines shelf life [14] Quality indicators will change due to the influence of environmental factors such as temperature, humidity and air pressure or due to the composition of the feed ingredients themselves. In this model it is assumed that the pollard and wheat bran damage factor is only caused by rancidity, so the data used in this model is the peroxide number data at several temperatures stored for 49 days.

\subsection{Application of the Arrhenius Model to Pollard}

Based on Table 1, there is a change in the value of the peroxide number in pollard at several temperatures during storage. According to [15] the content of free fatty acid in coffee increases during storage and unsaturated fatty acid decrease Based on the average value obtained, a regression equation can be made which shows a relationship between storage time and the value of in the pollard peroxide number at each different temperature. The following is the Pollard regression curve.

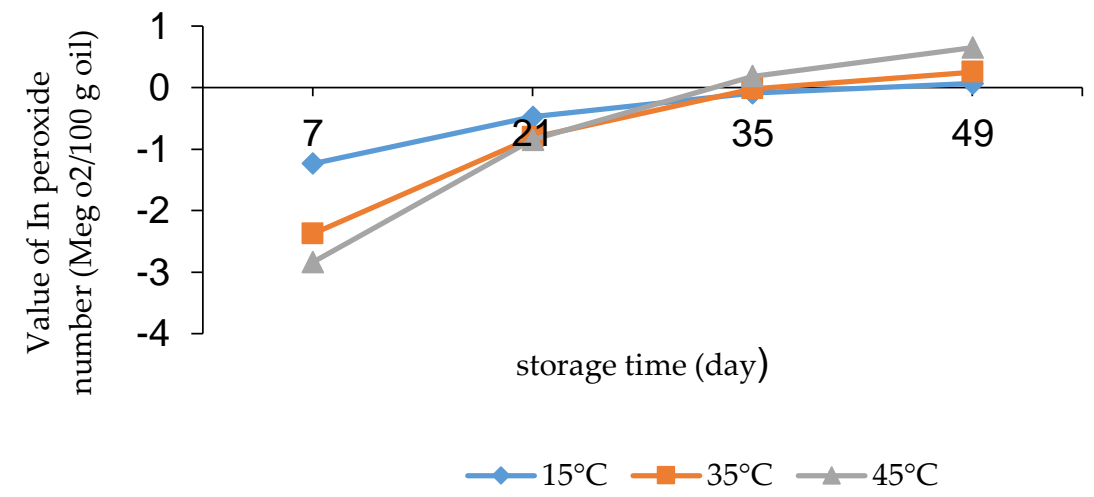

Figure 1. Graph of the long relationship of pollard storage to the in value of peroxide at 15,35 and $45^{\circ} \mathrm{C}$ 
In general, there is an increase in pollard peroxide numbers along with the length of storage time for both products stored at cold temperatures of $15{ }^{\circ} \mathrm{C}$, room temperature of $35{ }^{\circ} \mathrm{C}$ and warm temperatures of $45^{\circ} \mathrm{C}$. based on the graph above, the value of In, the peroxide number on the product shows a linearity pattern. It can be seen that the three linear equations for each storage temperature show a pattern of increase with each increase in temperature. Based on the graph in Figure 1, the In $\mathrm{k}$ value is obtained which will then be plotted to $1 / T$ into a graph.

Based on the graph of the relationship between In $\mathrm{K}$ and $1 / \mathrm{T}$, a constant rate of deterioration (k) of pollard with the addition of propionic acid is obtained, where the higher the temperature, the higher the rate of deterioration. If the rate of deterioration is higher, the shelf life of the pollard will be shorter. The constant rate of deterioration in the value of the pollard peroxide number at $15^{\circ} \mathrm{C}$ is $0.0015 /$ day, at $35^{\circ} \mathrm{C}$ is $0019 /$ day and at $45^{\circ} \mathrm{C} 0.0021$ /day The difference in the rate of deterioration is caused by the physiological processes of the material. Physiologically, after harvesting pollard, there is still a chemical reaction process in it and this process continues until decomposition occurs. Efforts to slow down this physiological process will slow down the decay process, carry out preservation at low temperatures, lower temperatures, the slower the process and the better, because for every $10^{\circ} \mathrm{C}$ the temperature decreases, the reaction speed is slowed down by approximately half [16]. So that the variation in storage temperature will greatly affect the shelf life of a product. Based on the quality degradation value obtained, it is continued to calculate the shelf life of the pollard.

Table 2. Value of quality decrease rate and shelf life of pollard based on peroxide number

\begin{tabular}{cccccc}
\hline Temperature $\left({ }^{\circ} \mathbf{C}\right)$ & Ea (kalori/mol) & Ko $_{\text { }}$ & K/day & Ts/day & Ts/month \\
\hline 15 & & & 0.0015 & 820.45 & 27.3 \\
35 & \multirow{2}{*}{1781.56} & 0.04 & 0.0019 & 666.97 & 22.2 \\
45 & & & 0.0021 & 393.28 & 13.1 \\
\hline
\end{tabular}

Based on Table 2, it can be seen that pollard when stored at $15^{\circ} \mathrm{C}$ produces the highest shelf life of 27.3 months, at $35^{\circ} \mathrm{C}$ it produces a shelf life of 22.2 months at a temperature of $45^{\circ} \mathrm{C}$ the lowest shelf life is 13.1 months.

\subsection{Application of the Arrhenius Model to Wheat Bran}

As seen in Table 1, there is a change in the value of the peroxide number in wheat bran. The longer the storage, the higher the value of the peroxide number formed. Based on the average value obtained, a form of regression equation can be made which shows a relationship between storage time and the value of the peroxide number at each different storage temperature. The following is an overview of the regression curve in the peroxide number with the storage time of wheat bran

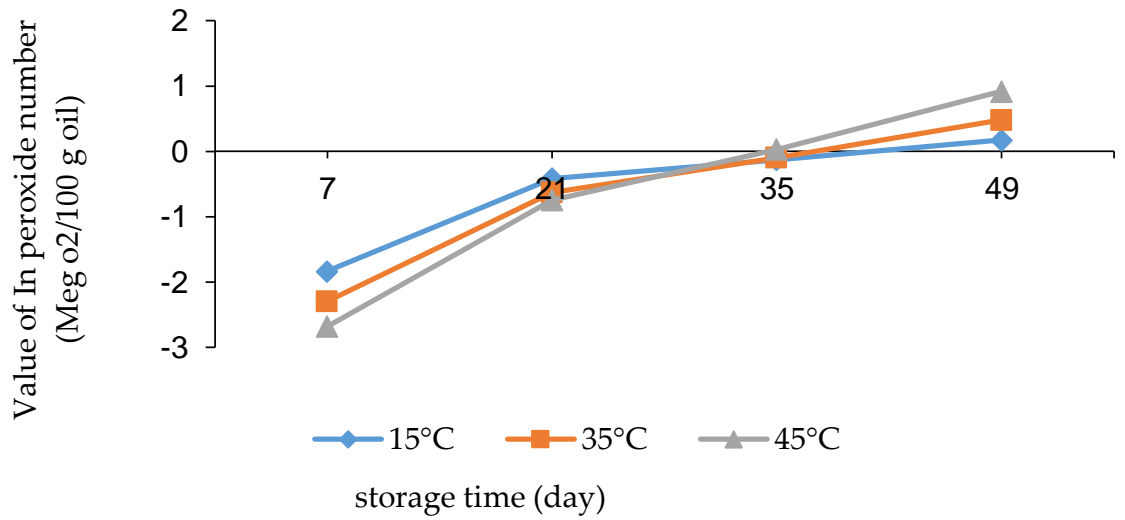

Figure 2. Graph of the relationship time of storage to the $\mathrm{k}$ value of the wheat bran peroxide number at 15.35 and $45^{\circ} \mathrm{C}$

In general, there is an increase in the value of the wheat bran peroxide number along with the length of storage time both at a cold temperature of $15^{\circ} \mathrm{C}$, a room temperature of $35^{\circ} \mathrm{C}$ and a warm 
temperature of $45^{\circ} \mathrm{C}$. based on the regression graph in Figure 2, the magnitude of the $\mathrm{k}$ value of the wheat bran peroxide number stored at 15,35 , and $45^{\circ} \mathrm{C}$, all show a linearity pattern. Based on this equation, the $\mathrm{k}$ value is obtained which will then be plotted by $1 / \mathrm{T}$ into the graph below.

Based on the graph of the relationship between $\mathrm{k}$ and $1 / \mathrm{T}$, the constant rate of decline $(\mathrm{k})$ of wheat bran is obtained, where the higher the temperature, the higher the rate of decline. if the rate of deterioration is higher, the shelf life of wheat bran will be shorter. The constant rate of deterioration of wheat bran at $15^{\circ} \mathrm{C}$ is $0.0014 /$ day, at $35^{\circ} \mathrm{C}$ is $0.0017 /$ day and at $45^{\circ} \mathrm{C}$ is $0.0018 /$ day. The results of calculating the value of the peroxide number in wheat bran against storage time will get a constant rate of deterioration. The rate of deterioration in the value of the wheat bran peroxide number follows the first order reaction which will then get the shelf life.

Table 3. Value of quality decrease rate and shelf life of wheat bran based on peroxide number

\begin{tabular}{cccccc}
\hline Temperature $\left({ }^{\circ} \mathbf{C}\right)$ & Ea (kalori/mol) & $\mathbf{K}_{\mathbf{o}}$ & K/day & Ts/day & Ts/month \\
\hline 15 & & & 0.0014 & 753 & 25.1 \\
35 & \multirow{2}{*}{774.54} & 0.021 & 0.0017 & 451 & 15.1 \\
45 & & & 0.0018 & 446 & 14.8
\end{tabular}

Based on Table 3, it is known that the higher the rate of deterioration constant, the lower the shelf life of the wheat bran and the higher the storage temperature, the faster the wheat bran is damaged. According to [17] higher storage temperature the greater the speed of deterioration/degradation $(\mathrm{k})$ resulting in shorter shelf life (ts).

\section{Conclusions}

Based on the results of the study, it can be concluded that the amount of temperature and storage time are directly proportional to the magnitude of the peroxide number. Meanwhile, temperature and storage time are inversely proportional to shelf life in terms of the Arrhenius model based on the peroxide number. In the Arrhenius model application, it is known that the best shelf life occurs at $15^{\circ} \mathrm{C}$, 27.3 months, while wheat bran occurs at $15^{\circ} \mathrm{C}$, which is 25.1 months. The suggestion in this research is to try the Arrhenius model test on other parameters as a comparison to determine the accurate shelf life

\section{References}

[1] V. Nurani, Y.A Widanti, "Pendekatan Umur Simpan Makanan Tradisional Berbahan Dasar Beras dengan Metode Accelerated Shelf Life Testing Melalui Pendekatan Arrhenius dan Kadar Air Kritis", Argoteknologi, vol. 14, no. 2, pp. 189-198, 2020.

[2] A. Tiwari, S.K. Jha, R.K. Pal, "Effects of Pre-Milling Treatments on Stor-Age Stability of Pearl Millet Flour", J Food Process, vol. 38, no. 1, pp. 1215-1223, 2014.

[3] C.S. Utama, Zupizal, C. Hanim, "Pengaruh Lama Pemanasan Terhadap Kualitas Kimia Wheat Pollard yang Berpotensi Sebagai Prebiotik", Jurnal Aplikasi Teknologi Pangan, vol. 8, no. 1, pp. 113122, 2019. https://:doi: 10.17728/jatp.5262

[4] P.V. Patty, "Pengaruh Lama Fermentasi Terhadap Ranciditas Minyak Kelapa Yang Diproduksi Secara Tradisional", Biopendix, vol. 15, no.1, pp. 146-152, 2015. https://:doi: 10.30598/biopendixvol1issue2page146-152.

[5] H. Haris, M. Fadli, "Penentuan Umur Simpan (Shelf Life) Pundang Seluang (Rasbora Sp) yang Dikemas Menggunakan Kemasan Vakum dan Tanpa Vakum", Saintek Perikanan, vol. 9, no. 1, pp. 53-62, 2014.

[6] H.P.S. Nagi, J. Kaur, Dar, "Effect of Strorage Period and Packaging on the Shelf Life of Cereal Bran Incorporated Biscuits", Am J Food Technol, vol. 7, no. 1, pp. 301-310, 2012.

[7] M.R. Hasany, E. Afrianto, R.I. Pratama, "Pendugaan Umur Simpan Menggunakan Metode Accelerated Shelf Life Test (ASLT) Model Arrhenius pada Fruit Nori", Perikanan dan Ilmu Kelautan, vol. 8, no. 1, pp. 48-55, 2014. 
[8] D.N. Suharman, R. Ekafitri, D. Desnilasari, "Estimation of Banana Snack Bar Shelf Life With Different Storage Temperarture Using Arrhenius Method", Biopropal Industry, vol. 11, no. 1, pp. 127-137, 2020. https://:doi: 10.36974/jbi.v11i2.5898

[9] N.K.M. Isadora, N.M. Wartini, N.S Antara, "Pengaruh Kombinasi Jenis Pelarut dan Perbandingannya Terhadap Karakteristik Ekstrak Buah Pandan (Pandanus Tectorius)", Rekayasa dan Manajemen Agroind, vol. 4, no. 1, pp. 47-58, 2016.

[10] S. Sulieman, J. Schulze, L.S.P. Tran, "Comparative Analysis of the Symbiotic Efficiency of Medicago Truncatulaand Medicago Sativa Under Phosphorus Deficiency", Internasional Journal Molecular Sci, vol. 14, no. 1, pp. 5198-5213, 2013. https://:doi: 10.3390//IJMS14035198

[11] M.R. Salim, Aplikasi Model Arrhenius untuk Pendugaan Masa Simpan Sosis Ayam pada Penyimpanan dengan Suhu yang Berbeda Berdasarkan Nilai TVB dan pH, Faculty of Food Industry Technology, Universitas Pasundan. Bandung, (Tesis), 2014.

[12] N. Asiah, L. Cempaka, W. David, Panduan Praktis Pendugaan Umur Simpan, UB Press, Malang, 2018.

[13] J. Crapse, N. Pappireddi, M. Gupta, "Evaluating the Simple Arrhenius Equation for the Temperature Dependence of Complex Developmental Processes", BioRxiv, vol. 4, no. 1, pp. 1-14, 2020. https://:doi: 10.1101/2020/07.17.208777

[14] R. Pertiwi, N. Suhartatik, A. Mustofa, "Estimasi Umur Simpan Beras Ketan Hitam (Oryza Sativa Var Glutinosa) dan Labu Kuning (Cucurbita Moschata) dengan Metode Accelerated Storage Studies", Jurnal Teknologi Hasil Pertanian, vol. 13, no. 1, pp. 104-110, 2020. https://:doi: 10.20961/jthp.v13i2.42944

[15] L. Kaprelyants, L. Pozhitkova, M. Buzhylov, "Application of Co-Bioprocessing Techiques (Enzymatic Hydrolysis And Fermentation) for Improving the Nutritional Value of Wheat Bran as Food Functional Ingrediens", Food Sci Tech, vol. 5, no. 1, pp. 31-45, 2019.

[16] S. Cong, W. Dong, J. Zhao, "Characterization of the Lipid Oxidation Process of Robusta Green Coffee Beans and Shelf Life Prediction During Accelerated Storage", Molecules, vol. 25, no. 1, pp. 116, 2020. https://doi: 10.3390/molecules25051157.

[17] A.B. Arif, "Metode Accelerated Shelf Life Test (ASLT) dengan Pendekatan Arrhenius Dalam Pendugaan Umur Simpan Sari Buah Nanas, Papaya dan Cempedak", Informatika Pertanian, vol. 25, no. 2, pp. 1-10, 2016. https://doi: 10.21082/ip.v25n2.2016.p189-198. 